\title{
IWRM Approaches in Water Resources Management Activities of BMDA, Barind Tract of Bangladesh: ABlooming Effort
}

\author{
Mohammad Iquebal Hossain ${ }^{1,2, ~ *, ~ M o h a m m a d ~ N i a m u l ~ B a r i ~}{ }^{1}$, Shafi Uddin Miah ${ }^{1}$, \\ Mohammad Selim Reza ${ }^{3}$, Chowdhury Sarwar Jahan ${ }^{4}$, Mohammad Rashidul Hasan ${ }^{5}$, \\ Mohammad Ferozur Rahaman ${ }^{6}$ \\ ${ }^{1}$ Deptartment of Civil Engineering, Rajshahi University of Engineering \& Technology, Rajshahi, Bangladesh \\ ${ }^{2}$ Barind Multipurpose Development Authority, Rajshahi, Bangladesh \\ ${ }^{3}$ Department of Economics, University of Rajshahi, Rajshahi, Bangladesh \\ ${ }^{4}$ Department of Geology and Mining, University Rajshahi, Rajshahi, Bangladesh \\ ${ }^{5}$ Deptartment of Civil Engineering, Bangladesh Army University of Engineering and Technology, Natore, Bangladesh \\ ${ }^{6}$ Institute of Environmental Science, University of Rajshahi, Rajshahi, Bangladesh

\section{Email address:} \\ iquebal_hossain@yahoo.com (M. I. Hossain), naimulbari@gmail.com (M. N. Bari), shafi_ruet@yahoo.com (S. U. Miah), \\ msreza06@ru.ac.bd (M. S. Reza), sarwar_geology@yahoo.com (C. S. Jahan), mrhasanraj@gmail.com (M. R. Hasan), \\ feroz90@gmail.com (M. F. Rahman) \\ ${ }^{*}$ Corresponding author
}

\section{To cite this article:}

Mohammad Iquebal Hossain, Mohammad Niamul Bari, Shafi Uddin Miah, Mohammad Selim Reza, Chowdhury Sarwar Jahan, Mohammad Rashidul Hasan, Mohammad Ferozur Rahaman. IWRM Approaches in Water Resources Management Activities of BMDA, Barind Tract of Bangladesh: ABlooming Effort. Hydrology. Vol. 8, No. 4, 2020, pp. 91-97. doi: 10.11648/j.hyd.20200804.15

Received: November 17,2020; Accepted: November 27, 2020; Published: December 8, 2020

\begin{abstract}
Barind Tract of Bangladesh, located in its North-West region is a drought prone water stressed area facing serious setback in water management for agriculture, drinking, domestic and other uses. Barind Multipurpose Development Authority (BMDA) has been working relentlessly to overcome such hostile situation introducing, devising and adopting various techniques, methods and technologies in an integrated way since 1986. So, the aim of present study is to discuss the attemptsand find the impacts of Integrated Water Resources Management (IWRM) activities taken by BMDA for groundwater and surface water augmentation, rainwater harvesting, drinking water supply and irrigation water management. In this view necessary data and information related to the water resources development and managementactivities were collected from BMDA, field investigation and other sources and analyzed them. The study finds that due to IWRM approaches in water resources augmentation and management activities of BMDA, rainfall dependent single cropped land has been converted multi cropped land, water losses have been reduced, rural people are getting potable drinking water and the desert like Barind Tract area has been converted into a granary one. Attention needs to be given to augment and use more surface water as well as rainwater and maintain the irrigation and drinking water infrastructures on a regular basis for sustainable crop production, drinking and other uses of water.
\end{abstract}

Keywords: Groundwater, Rain Water, Surface Water, IWRM, Barind Tract

\section{Introduction}

The part of greater Rajshahi, Rangpur, Dinajpur and Bogra district of Bangladesh and Indian territorial Maldah district of west Bengal is geographically identified as Barind Tract. In
Bangladesh, theBarind Tract located in its north-west part is the largest Pleistocene terrace of the country made up of the Pleistocene alluvium, also known as older alluvium floored by reddish brown, sticky Pleistocene sediment; MadhupurClay and which elevation above sea level varies 
from a minimum of $14 \mathrm{~m}$ to a maximum of $45 \mathrm{~m}$. [1-6]. Tectonically the area is in the stable shelf region of the Bengal Basinwhichphysiographically covers both the floodplain and the Barind Tract. The Tract is located in between 24 degree 23 minute to 25 degree 15 minute north latitude and 88 degree 2 minute to 88 degree 57 minute east longitude and is divided into three major parts like Level Barind, High Barind and North Eastern Barind [7]. The hard red soil, typical dry climate with comparatively high temperature and less rainfall of the BarindTract are very significant in comparison to that of the other parts of the country [8]. Temperature of the area varies from 8 degrees Celsius to 44 degrees Celsius [2]. Annual rainfall ranges from $1250 \mathrm{~mm}$ to $2000 \mathrm{~mm}$, on the contrarynational average is $2500 \mathrm{~mm}$ and almost $80 \%$ of the rainfall occurs in the area during June to October [9]. Rain water is the only source of recharging groundwaterbecause almost of the area is flood free $[9,10]$. But the thick top clay layers restrict the percolation of storm water to the groundwater [11] and low infiltration capacity (2-3 mm/day) [12] causes thelessening of the natural recharging of groundwater [13]. Surface water sources are very limited and most of which like pond, canal, river and other natural water bodies get dried up during dry season. Crop productionof the Tract was entirely dependent on rainfall before 1986. Only rain-fed T-Amon (local name of paddy) crops were grown here whose cultivation used to be hampered in want of rainfall in right time and field crops were damaged very often. After cultivation of T-Amon, the land remained uncultivated for the rest time of the year and used as the grassing land for the cattle and then farmers did not have any work to do. Because of this reason people of this area were too poor and regularly migrated to other places of the country in search of job. They used to drink pond water. So they suffered from lots of water born diseases [8]. When the ponds were dried in dry season they had to face serious setback in collecting water to drink. The slogan, "Barind is a land where life is written in water" is known to the people of the area [3]. So, life was not easy and the area was completely underprivileged and under developed.

To overcome suchantagonistic situation of the area, a project titled "Barind Integrated Area Development Project (BIADP)" was taken for the development of Barind tract covering 15 Upazilas (sub-district) of Rajshahi, Chapaiwawabgonj and Naogaon districts [14]. Among others, the main objective of the project was to increase crop production through creation of irrigation facilities and to help achieving food security. To expedite the development activities of the Barind Tract, a separate authority named Barind Multipurpose Development Authority (BMDA) was created on $15^{\text {th }}$ January 1992 under the Ministry of Agriculture, Bangladesh [15]. The jurisdiction was further expanded to cover the whole area of Rajshahi and Rangpur divisions consisting of 16 districts. Irrigation was started through utilization of groundwater by installing Deep Tube Wells (DTW) as the there were very little sources of surface water along with low rainfall. Thus irrigation as well as crop production becomes dependent and groundwater. Though the development projects have significant impact in changing living standard and socio-economic conditions of the rural people in Barind Tract area [10] but groundwater level started to decline due its over extraction mainly for irrigation. In addition, less rainfall, low infiltration due to thick top clay, poor flow of water in the river have posed the over stresses on groundwater causing continuous depletion of groundwater level in manyareas of Barind Tract and groundwater extraction has become unsustainable in some area of barind tract $[16,17]$. Moreover, lack of governance in water sector further aggravates the over exploitation of groundwater and declining of GWL situation [18] in the area.

IWRM tool helps to solve the situation mentioned above in water management. The Integrated Water Resources Management (IWRM) is defined as "a process which promotes the coordinated development and management of water, land and related resources in order to maximize the resultant economic and social welfare in an equitable manner without compromising the sustainability of vital ecosystems [19]. Cross sectoral integration of IWRM is water for people, water for food, water for nature and water for industry and other users.

In this context, BMDA has applied IWRM approaches in the water resources management activities. The aim of the study is to give focus on water resources management attempts and assess impacts of IWRM in water resources activities.

\section{Methodology}

\subsection{Study Area}

The study area is located in the North-West region of Bangladesh which covers 125 upazilas of all the 16 district of Rajshahiand Rangpur divisions under the Barind Tract (district and upzila are second and third tire of the administrative unit of Bangladesh). The area is mostly drought prone and groundwater is the main sources of irrigation for agricultural crop production, drinking, domestic and industrial uses. The location map of the study area is in Figure 1.

\subsection{Data Collections and Analysis}

Different data like information about Deep Tube Wells (DTWs) for groundwater extraction, re-excavated canals, ponds, cross dam (check dam), rubber dam for surface water augmentation, dug well and recharge well for rain water harvesting and groundwater recharge, buried pipe line, drinking water supply installations, prepaid meter for irrigation water management and other necessary information have been collected from the Barind Multipurpose Development Authority (BMDA), field investigation and other sources. 


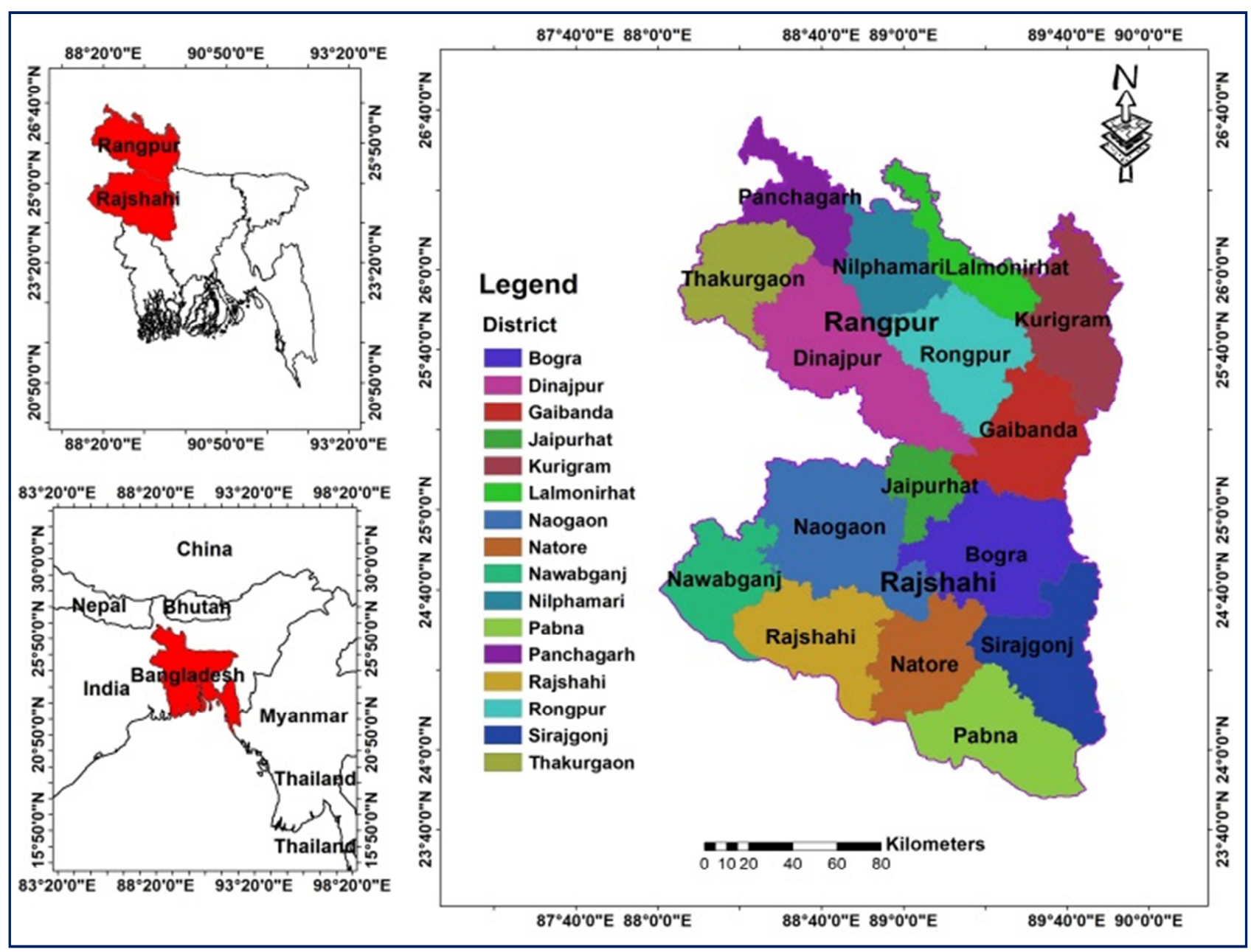

Figure 1. Location map of the Study Area.

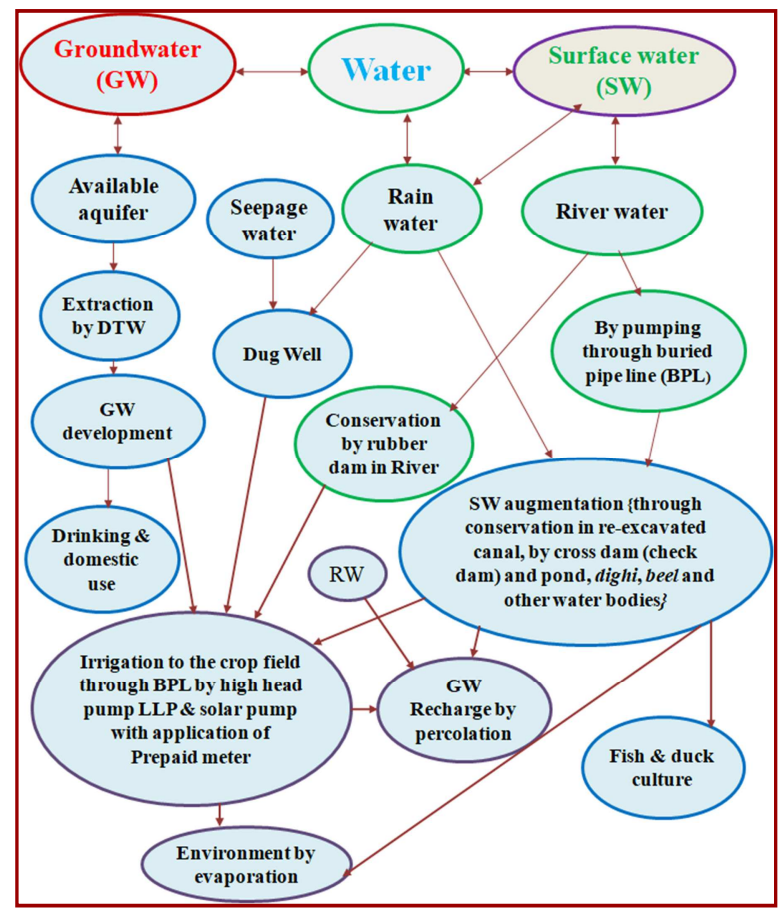

Figure 2. IWRM approaches in BMDA's water resources management activities.

\subsection{Description of IWRM Activities of BMDA}

BMDA has been trying to use water resources for crop production, drinking, domestic and other purposes in a sustainable manner and to adapt with the climate change, adopting the concept of Integrated Water Resources Management (IWRM). For this BMDA has taken lots of initiatives for the development ofgroundwater, augmentation of surface water, management ofirrigation water, harvesting of rain water, providing drinking water, increasing irrigation efficiency by minimizing the conveyance loss andjudicial use of irrigation water through applications of buried pipe lineand digital prepaid meter. The total activities of the water resources management of BMDA with an integrated way can be seen in a single diagram as shown in the following Figure 2. Water is in the central part which may be groundwater or surface water. Groundwater comes from available aquifer; main sources of surface water are rain water, river, canal, pond water and water from other natural water bodies.

The brief of IWRM approaches in the water management activities are summarizedbelow:

\subsubsection{Groundwater Development, Irrigation and Drinking with Domestic Usages}

Irrigation was started in the Barind Tract area with 
groundwater through installation of DTW as the source water sources are very limited leading to groundwater as the main source of irrigation, drinking and other uses. DTW is installed where there is accessible aquifer and used to withdraw groundwater for mainly irrigation. Irrigation water is distributed to the crop field through buried pipe line (underground pipe line) to minimize the conveyance loss as well as evaporation loss. Valuable agricultural land loss is also minimized as the pipe line remains beneath the ground surface. A part of irrigation water from the crop field recharges groundwater as percolation and the otherpart get back to the atmosphere as evaporation. Figure 3 shows a DTW with buried pipe line water distribution system.

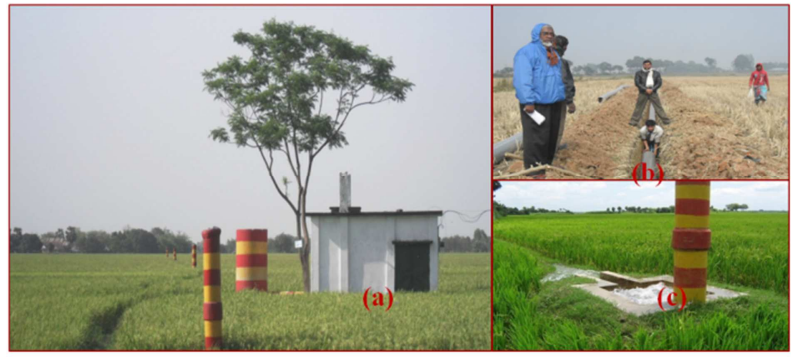

Figure 3. (a) an irrigation scheme with a DTW and buried pipe line, (b) buried pipe line under laying stage and (c) an outlet for discharging water from pipe line to the field.

About $15 \%$ of the installed DTWs are located near the villages which are used to provide potable dirking water to the rural people of the water scarce Barind Tract alongside irrigation. Drinking water is supplied to the beneficiaries through construction of a 25000 liter capacity overhead water tank along with a pipe network. People of the rural area are now getting water for drinking and domestic uses at their door step. The details are shown in Figure 4.

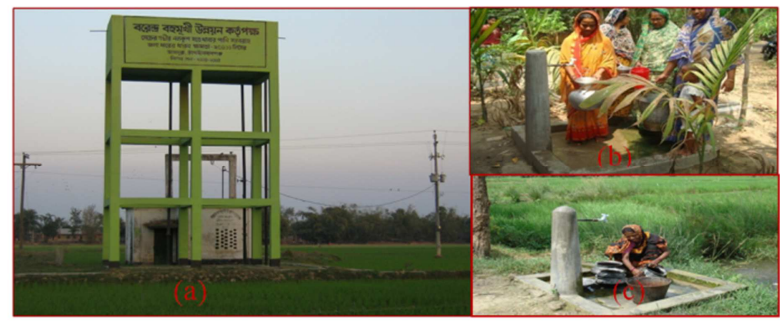

Figure 4. (a) an over head water tank beside an irrigation DTW,(b) villager women are collecting water for drinking purposes (c) an woman is washing utensils using the water from the system.

\subsubsection{Surface Water Augmentation and Irrigation}

Both the river water and rainwater are augmented as surface water mainly for supplementary irrigation.

i. Storm Water Augmentation

Derelict canals, ponds/dighis (bigger pond), Beels (natural water body larger than dighi) are re-excavated to augment (conserve) storm water. Water control structures like cross dams (check dams) are constructed in the re-excavated canals at different sections for water storing purposes. The storm water augmentation structures are shown in Figure 5.

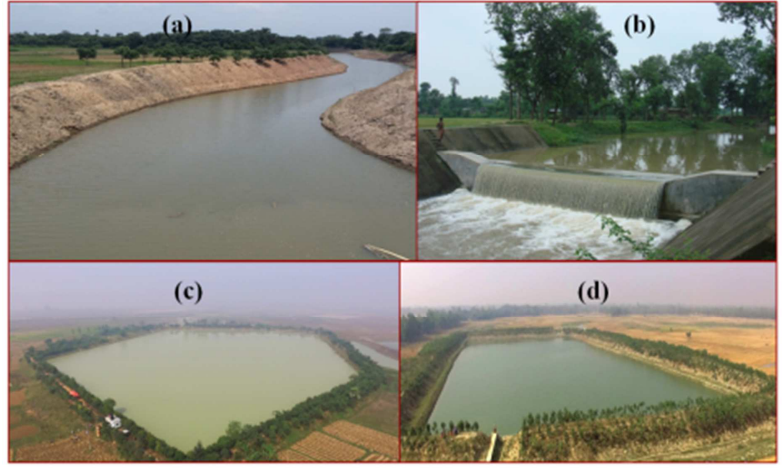

Figure 5. (a) a re-excavated canal, (b) a cross dam (check dam) in the reexcavated canal, (c) a re-excavated pond and (d) re-excavated portion of a natural beel.

The conserved water is then withdrawn by electricity driven or solar driven Low Lift Pump (LLP) and conveyance to the crop field through buried pipe line as shown in Figure 6. Some parts of the conserved water from the canals, ponds and beelsand irrigated fields helps recharging groundwater through percolation and support environment by evaporation.

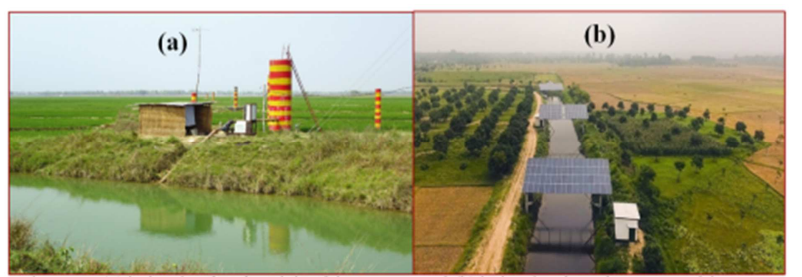

Figure 6. (a) irrigation by electricity driven LLP and (b) irrigation by solar energy driven LLP.

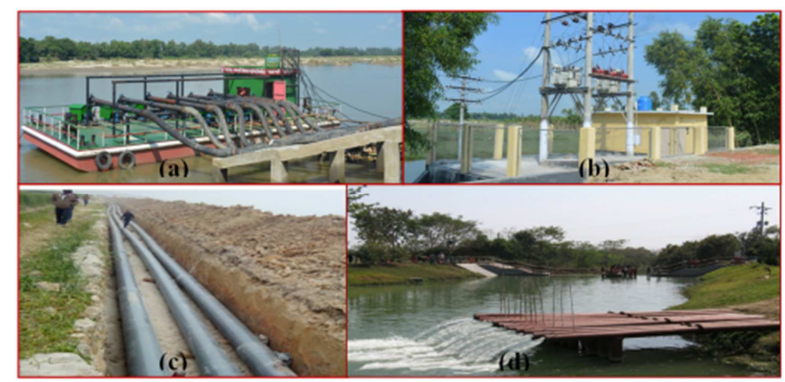

Figure 7. (a) Pontoon with centrifugal pumps and armed hose pipes, (b) Electric Sub-station (c) Underground pipe lines to carry river water to the canal, ponds or places to be irrigated, (d) discharging river waterto the canal.

\section{ii. River Water Augmentation}

At the perennial source point of river, BMDA constructs floating pontoons and on which centrifugal pumps are placed with rubber made flexible armed hose pipe with the intention that no problem take place when pontoon moves upward and downward with rise and fall of water of the river during rainy season and dry season. To operate the pumps, each pontoon has an electric substation with required capacity at the river bank near the pontoon. Pumps extract water from the river and transmit it to the re-excavated canal, ponds or irrigation points at distant places through underground pipe lines made 
of unplasticised polyvinyl chloride (UPVC) or mild steel (MS) constructed beneath the ground surface. The infrastructures are shown in Figure 7.

Rubber dam is also constructed across the river to conserve water at the upstream of the dam (as shown in Figure 8) and the conserved water is used toirrigate crop field by LLP and buried pipe line.

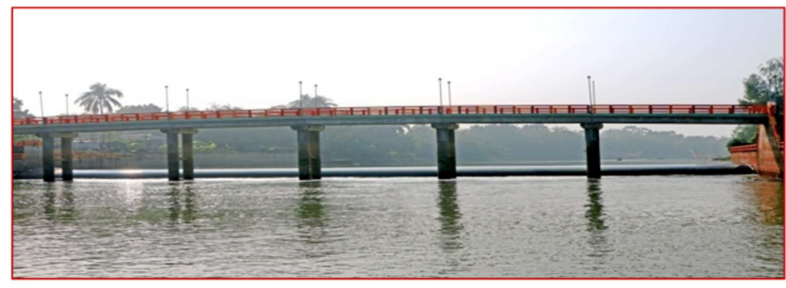

Figure 8. A rubber dam constructed across the river Barnai.

\subsubsection{Dug Well $(D W)$ for Irrigation}

DW is constructed to irrigate low water consuming crops like cauliflower, potato, chilies and other vegetables at the severe water scarce area where there is neither surface water nor groundwater sources. Water comes to the DW from the surrounding formation as leaching. The conserved water is then lifted to the overhead tank by solar energy driven pump and used for irrigation. Solar panel (produce solar energy) cum rain water receiving structure receives storm water and put it to the DW which is further withdrawn for irrigation and in some area also for drinking use. DW water is also helps recharging groundwater. The detailed of DW is shown as Figure 9.

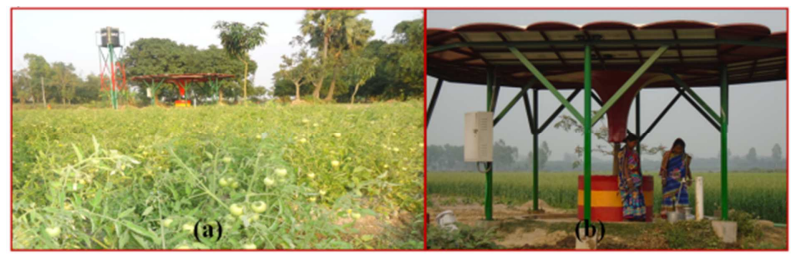

Figure 9. (a) irrigation to the vegetable field by $D W$ and (b) women are collecting drinking water from a $\mathrm{DW}$.

\subsubsection{Prepaid Metering inIrrigation Water Management}

BMDA introduces prepaid metering system in the irrigation management to reduce the over use of valuable water. In this system each farmer is provided prepaid card (user card). Farmers recharge their prepaid cards by giving certain amount of money tothe authority or dealear recruited by BMDA. Whenever a farmer needs irrigation water, he inserts his card into the prepaid meter of the irrigation equipment like DTW or Low Lift Pump (LLP). The irrigation pumpthen starts running automatically and provides irrigation water if there is balance in the card. If the balance of the inserted card is finished or the card is taken out from the meter, the DTWgets offatonce automatically. As it is a prepaid system, farmers receive irrigation water only for the actual need of crop field. So over use of irrigation water is reduced with lessening irrigation cost. It is anenvironment friendly technology and acceptable to the farmers level. In this system, the irrigation activities can be monitored centrally following the digital way through internet. Now It is possible to cultivate the crops with less water and cost for all the farmers of an irrigation sheme throughout the year. The system is shown as Figure 10.

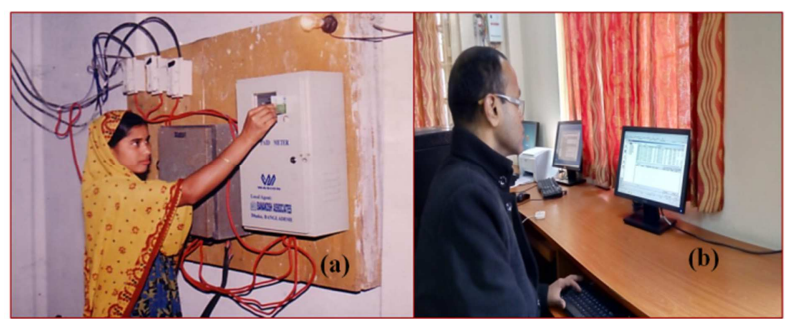

Figure 10. (a) a lady farmer is inserting her prepaid card into the prepaid meter of the irrigation equipment and (b) The total system is being monitored from the head quarter of BMDA using internet net work.

\subsubsection{Recharge Well (RW) for EnhancingGroundwater Recharge}

Recently BMDA has started to recharge groundwater using Managed Aquifer Recharge (MAR) technique like RW on experimental basis. A RW has been installed in BMDA Mohanpur office campus. When rainfall occurs, roof water from office building and training shed flows down to the water filtration unit and is filtered there and then groundwater is recharged by filtrated water through the strainer of RW. The MAR system including Recharge Well is shown in Figure 11.

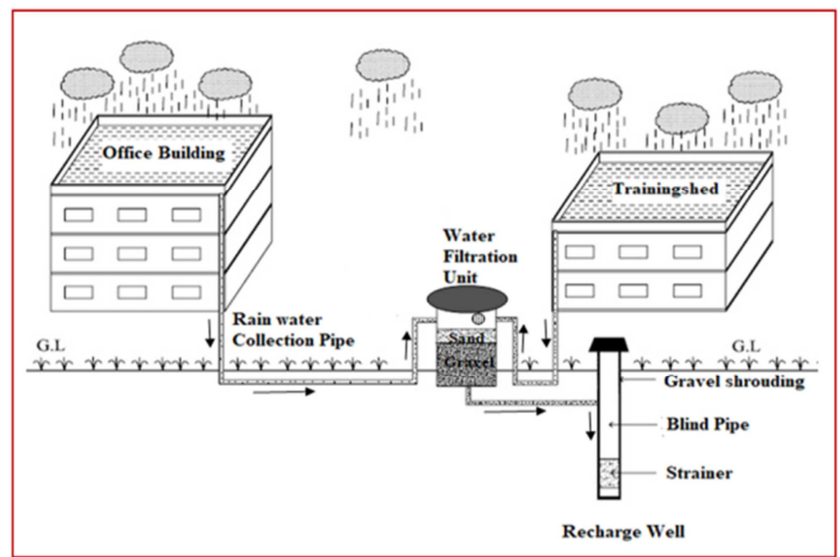

Figure 11. Managed Aquifer Recharge (MAR) system including $R W$ at BMDA Mohanpur office campus.

\section{Findings and Discussions}

The findings are presented with discussion in the following sections.

\subsection{Reduction in Conveyance Loss as Well as Increase in Irrigation Efficiency and Saving Land}

In earthen channel conveyance loss of irrigation water is more than $40 \%$ which has been reduced due to construction of buried pipe line water distribution system. The average conveyance efficiency of uPVC buried pipe lined DTW 
scheme ranges from $94.46 \%$ to $95.37 \%$ and rate of water loss ranges from $5.45 \%$ to $6.11 \%$ and about $80 \%$ farmers recommends BMDA's buried pipe line is sustainable to increase productivity of irrigation systems in Bangladesh [20]. Also 1 bigha (33 decimals) of land used to be lost due surface channel for a 2 cusec capacity DTW scheme which has been possible to minimized [21]. So, a total of 1928 hectares of land have been saved for the 15882 DTW schemes.

\subsection{Introduction of Prepaid Meter Reduces over Use of Irrigation Water and IncreasesCommand Area}

Over use of valuable irrigation water has been reduced and results in increased in command area by $22 \%$ due to introduction of prepaid meter in irrigation management [22]. The average irrigation cost for Private Practiced Irrigation System (PPIS) is about $112 \%$ higher than the Prepaid Meter Irrigation System (PMIS) and the average irrigation water quantity for PPIS is $39 \%$ higher than the PMIS [23]. Moreover, in this system irrigation charge is realized automatically and no scope of pending irrigation charge. There is no scope of cheating farmer by any operator or middle man and farmer gets full water as per his expended money. There is no scope of meter tempering. Any tempering or tempering attempt can be identified from the meter.

\subsection{Achievements Due to Groundwater Irrigation}

Total numbers of installed and rehabilitated DTWs are15882, length of constructed and extended buried pipe lines are $13292 \mathrm{~km}$ and by which 522000 hectares of land has been possible to bring under controlled irrigation facilities up to June, 2019.

\subsection{Achievements Due to Surface Water Irrigation}

Total numbers of re-excavated ponds are 3098, length of reexcavated canal is $2001 \mathrm{~km}$ and 747 numbers of cross dam have been constructed at different sections of re-excavated canal to hold storm water and to use river water for irrigation, 11 numbers of floating pontoons with requiredpumps have been set up on the river Padma, Mohanonda and Atrai. Beside these, one rubber dam has been constructed across the river Baranai for storing water at its upstream. 519 numbers of electricity driven LLP and 106 numbers of solar energy driven LLP are used to withdraw surface water from the ponds and canals and due to construction of these surface water infrastructures, 97000 hectares of land have been brought under supplementary irrigation in a control way until June, 2019.

\subsection{Achievements Due to Irrigation by Dug Well (DW)}

It has been possible to bring 300 hectares of land under irrigation of low water consuming crops like potato, cauliflower, chilies, tomatochickpea etc. until June, 2019. A considerable numbers of underprivileged village people are also getting drinking and domestic water from the DWs that need to be found out with proper study.

\subsection{Achievements Due to Drinking Water Supply Installation}

Till to June 2019, 1579 numbers of drinking water supply installation have been constructed close to the irrigation DTWs which are providing potable drinking water to 900000 village people. Now the rural people of the respective areas of installations do not have to collect or drink pond water and they are much better with their health from suffering of water borne diseases.

\subsection{Enhancement of Ground Water Recharges}

In a year about 300000 liters of rooftop rain water percolate to the aquifer through one Recharge Well installed at the BMDA Mohanpur office campus and groundwater is recharged. More office campus of BMDA and other organizations need to bring under such program. Experiences show that a significant portion of the conserved water from the re-excavated ponds, canals and other water bodies percolate and recharge groundwater which need to be quantified through research and study.

\section{Conclusions}

The water scarce desert like Barind Tract located in the northwestern part of Bangladesh has become a sociable living area due to water resources augmentation and management activities following the IWRM approaches as a blooming effort by BMDA. Due to installation of 15882 numbers of DTWs along with prepaid meter and $13292 \mathrm{~km}$ buried pipe line, 522000 hectares of land are now under groundwater irrigation and 97000 hectares are under surface water irrigation because of reexcavating 3098 numbers of derelict ponds, $2001 \mathrm{~km}$ canals along with 747 numbers of cross dam, river water irrigation by installing 11 pontoons with pumps on the river Padma, Mohananda and Atrai and constructing a rubber dam across the river Barnai. Buried pipe line has increased conveyance efficiency ranging from $94.46 \%$ to $95.37 \%$ with saving of 1928 hectares of land for the 15882 DTW schemes compared to surface channel. Utilization of prepaid meter has reduced the overuse use of irrigation water and thus increased command area by $22 \%$. Above and beyond 900000 village people are now getting potable drinking water from the 1579 drinking water installations. Augmented surface water from the re-excavated water bodies and irrigation water from the crop fields help recharging groundwater significantly and developing environment alongside irrigation which needs detail research to find the actual quantity of recharge. By one installed Recharge Well, 300000 liters of rooftop rain water recharges groundwater in a year. Roofs of other office buildings, training sheds, buildings of educational institutions, factories/commercial buildings and residential buildings/houses need to be brought under Managed Aquifer Recharge program to enhance groundwater recharge. More canals and ponds should be reexcavated to conserve more surface water and use more river water and periodic maintenance of themis needed for sustainable operation. For proper planning and management, scientific 
assessment of groundwater as well as surface water resources with zoning are needed.

\section{References}

[1] K. M. Ahmed, "Barind Tract", Banglapedia, National Encyclopedia of Bangladesh. Retrieved from (http://en.banglapedia.org/index.php?title=Barind_Tract), 2006.

[2] M. Ahmeduzzaman, K. Shantanu., A. Asad, "A Study on Ground Water Fluctuation at Barind Area, Rajshahi", International Journal of Engineering Research and Applications (IJERA), 2012, Vol. 2, Issue 6, pp. 1465-1470.

[3] Barind Multipurpose Development Authority (BMDA), "Barind Authority: Past-Present, 2006.

[4] I. Matin, "Groundwater of barind tract-its condition and potentiality", 33rd AnnualConvention ofInstitution of Enginners, Bangladesh, Dhaka, March 27-30, 1989.

[5] R. A. Khandoker, "Origin of elevated BarindMadhupur areas, Bengal Basin: Results of neotectonic activities", Bangladesh Journal of Geology, 1987, 6: 1-9.

[6] IWM (Institute of Water Modelling), “Groundwater Model Study for Deep Tubewell Installation Project in Barind Area", 2006, Final Report, Volume-III.

[7] BMDA (Barind Multipurpose Development Authority), "Final Report on BarindEnvironmental Action Plan (BEAP)", 2003.

[8] BMDA (Barind Multipurpose Development Authority), "Development Activities of BMDA, Rajshahi, Bangladesh", 2018.

[9] IWM (Institute of Water Modelling), "Groundwater Resources Study and Decision Support System Development of Rajshahi, Naogaon, ChapaiNawabganj, Pabna and Natore Districts and Also RemainingDistrict of Rajshahi Division through Mathematical Model Study for Barind Integrated AreaDevelopment Project, Phase-III", 2012, Final Report, Volume I.

[10] M. Rahman and A. Q. M. Mahbub, "Groundwater Depletion with Expansion of Irrigation in Barind Tract: A Case Study of TanoreUpazila", Journal of Water Resource and Protection, 2012, 4, 575-567, doi.org/10.4236/jwarp.2012.48066).

[11] M. I. Hossain, N. Bari, S. U. Miah, "Operational Constraints in Conventional Managed Aquifer Recharge in Barind Area at North-Western Region of Bangladesh", Proceedings of $2^{\text {nd }}$ International Conference on Planning, Architechture\& Civil Engineering, Faculty of Civil Engineering, Rajshahi University of Engineering \& Technology, Rajshahi, 07-09 February, 2019a.

[12] C. S. Jahan, Q. H. Mazumder, M. I. Adham, M. M. A. Hossain, Al-M. Haque, "Study on Groundwater Recharge Potentiality of Barind Tract, Rajshahi District, Bangladesh Using GIS and Remote Sensing Technique", Journal of Geological Society of India, 2010a 75: 432-438.
[13] C. S. Jahan, A. T. M. S. Rahman, Q. H. Mazumder and M. Kamruzzaman, "Adaptation for Climate Change Effect on Groundwater Resource through MAR Technique in Drought Prone Barind Area, Rural Bangladesh”. In S. M. Ali (Ed.), Bangladesh: Combating Land Degradation and Drought. Dhaka: Series-II, Department of Environment (DoE), Ministry of Environment (MoEF), GoB, 2015, 61-83, ISBN 978-98433-9991-5.

[14] A. H. M. R. Imon and M. Ahmed,"Water Level Trend in Barind Area", Malaysian Journal of Mathematical Sciences, 2013, 7 (1), pp (1-15).

[15] BMDA (Barind Multipurpose Development Authority), "Development Activities of BMDA, Rajshahi, Bangladesh", 2019.

[16] A. T. M. S. Rahman, C. S. Jahan, Q. H. Mazumder, M. Kamruzzaman, T. Hosono, "Drought Analysis and its Implication in Sustainable Water Resource Management in Barind Area, Bangladesh", Journal of Geological Society of India, 2017, 89 (1), 47-56. https://doi.org/10.1007/s12594017-0557-3.

[17] M. A. Mojid, M. F. Parvez, M. Mainuddin, G. Hodgson, "Water Table Trend-ASustainability Status of Groundwater Development in North-West Bangladesh", Water, MDPI Publishing, 2019, doi.org/10.3390/w11061182.

[18] M. R. Islam, C. S. Jahan, M. F. Rahman, Q. H. Mazumder, "Governance status in watermanagement institutions in Barind Tract, Northwest Bangladesh: an assessment based on stakeholder's perception", Sustainable Water Resources Management, 2020, 6: 21, doi.org/10.1007/s40899-02000371-1.

[19] GWP (Global Water Partnership),"Integrated Water Resources Management, 2000, TAC Background Papers No. 4, Global Water Partnership: Stockholm. 67 p.

[20] Md. Mosiur Rahman, A. H. M. Kamal, Abdullah and Md. Shafi Uddin Miah, "Study on the Irrigation waterdistribution system developed by Barind Multipurpose Development Authority", Journal of the Bangladesh Association of Young Researchers (JBAYR), 2011, Volume 1, Number 2, June 2011 , Page: 63-71.

[21] BMDA (Barind Multipurpose Development Authority), "Development Project Proposal of Command Area Extension and DevelopmentProject", 2010.

[22] Asaduzzaman, "Replication of the Barind Model to Muhuri Irrigation Project. Moving from Water Problemsto Water Solutions: Research Needs Assessment for the Eastern Gangetic Plains", Proceedings of the International Workshop held at the National Agricultural Science Complex (NASC), Indian Council of Agricultural Research (ICAR), New Delhi, India, May 7-8, 2013.

[23] Md. A. Kasem, "The economics of prepaid irrigation: Barind Multipurpose DevelopmentAuthority (BMDA) perspective $\mathrm{PhD}$ Thesis", 2009, Atlantic National University 5543, 1/2 Santa Anita Avenue, Temple City California, CA- 91780 USA. 